\title{
Long Acting Reversal Contraception: Perceptions of High School and Undergraduate Students on a Medical Track
}

\author{
Sanika Gadkari BS, Joshua Kraft MD, Ashley Thompson MD, Michael Roche MD and Stephen Wagner MD* \\ Penn State Hershey Medical Center, USA
}

Submission: June 15, 2017; Published: June 30, 2017

*Corresponding author: Stephen Wagner, Penn State Hershey Medical Center, USA, Email:swagner2@pennstatehealth.psu.edu

\section{Introduction}

Despite being the only reversible, top tier, form of contraceptive, currently less than $13 \%$ of women utilize LARCs, or long acting reversible contraceptives (American College of Obstetricians and Gynecologists, 2015; American Congress of Obstetricians and Gynecologists, 2011) [1]. LARCs are classified into 3 types: Copper Intrauterine device (IUD), levonorgestrel Intrauterine device, and Etonogrestrel rod contraceptive implants. These three forms of contraceptives are thought to be just as effective as irreversible female sterilization methods and last for anywhere from 3-10 years [2,3]. Unlike other forms of contraceptives, studies have found that women prefer these methods, which have a rapid return to fertility after stopping their use and a lack of day-to-day administration [4]. Furthermore, there are very few restrictions as to who is eligible to receive LARCs. According to the CDC and WHO, there are only 3 groups of women who should be cautious with LARC use: women who are postpartum and breast feeding, those who are at increased risk for deep vein thrombosis or pulmonary embolisms, or women who are at increased risk of uterine fibroids with uterine distension $[4,5]$.

The copper IUD is a T shaped device wrapped in copper wire that is placed in the uterus and thought to exert mostly pre-fertilization inhibition. This includes inhibition of sperm migration and viability and destruction of the ovum before fertilization [1-3]. The levonorgestrel IUD is a similar T shaped device as seen with copper IUDs, but instead of being wrapped in copper, it secretes a form of progesterone. In addition to the pre-fertilization effects seen with copper IUDs, there is also an alteration of the amount and thickness of the cervical mucus as well as suppression of endometrial growth. These changes have an effect on the ability of sperm to enter the uterus as well as an effect on the ability of an egg to successfully implant in the endometrium [6]. The copper IUD has been approved for use up to 10 years while the levonorgestrel has been approved for up to 5 years. Lastly, the etonogestrel rod contraceptive implant is a single rod that is placed sub-dermally and continuously secretes etonogestrel, a form of progesterone, which suppresses ovulation by altering the Hypothalamus-Pituitary-Ovarian axis and by altering the thickness of the cervical mucus, once again successful sperm entry into the uterus [6-9].

Due to the lack of day-to-day administration, LARCs have been implicated in significant reduction in pregnancy rates in populations that do use them. Yet, despite all the benefits, very few women use them, with the most common reasons being barriers to access $[5,10,11]$. These barriers include higher upfront costs, lack of provider training, and patient awareness. Despite higher upfront costs, studies have shown that LARCs, such as IUDs, are found to be the cheapest contraceptive method over the course of 5 years [12]. Without financial barriers, patients can often run into the issue of not finding a trained provider to perform the insertion. For example, the contraceptive implant requires special training before performing the procedure [5]. Communities which may experience lack of healthcare access overall, may not have access to a physician who is able to perform LARC procedures. Lastly, one of the major theorized barriers to access is the lack of patient education regarding LARCs. LARCs can be used in many different scenarios, are extremely effective and have very few, rare, complications however, most women are still unaware of these advantage [13]. The gap in education regarding LARCs will be the main focus of our study.

\section{Methods}

A "primary care workshop" was arranged through the family medicine department at a tertiary care academic center. Target participants were undergraduate students from a number of local colleges and universities who had expressed an interest in pursuing careers in medicine. This single day event entailed a number of lectures, and a variety of small group "breakout" sessions where individuals could obtain additional education in areas of interest. 
Residents in obstetrics and gynecology were invited to participate and lead a "breakout" session on contraception. These 30 minute sessions involved both a structured lecture and then a simulation aspect. During the simulation students were invited to place implants and IUDs on mannequins. Immediately prior to and after these sessions students were invited to complete voluntary surveys to assess their knowledge on the subjects covered during the presentation.
45 students in total participated in the four "breakout" sessions offered on contraception. Of these 45, 42 elected to complete the surveys. Following completion the data was collected and compiled in Microsoft Excel. Statistical analysis was performed with both Microsoft Excel and Graphpad Quickcalc. Student $\mathrm{T}$ tests were utilized and $\mathrm{p}$ values $<.05$ were considered significant.

\section{Results}

Table 1: Pre and Post workshop rankings for efficiency of contraceptive methods (1=most efficient, $5=$ least efficient).

\begin{tabular}{|c|c|c|c|c|c|}
\hline & \multicolumn{4}{|c|}{ Efficiency Of Contraceptive Method (Scale Of 1-5, 1= Most Efficient) } \\
\hline $\mathbf{n = 4 2}$ & Condom & Implant & OCP & Withdraw & 2.425 \\
\hline Pre-Workshop & 3.128 & 2.436 & 2.462 & 4.513 \\
\hline Post-Workshop & 3.556 & 1.889 & 3.028 & 4.972 & 0.111 \\
\hline P value & 0.069 & 0.0356 & 0.005 & 0.852 \\
\hline
\end{tabular}

On a Likert scale of $1-5,1$ being the most efficient, the average perceived efficiency of each method changed from preworkshop to post workshop. As seen in Table 1, the perceived efficiency of Implant and OCPs both showed a significant change with $\mathrm{p}$-values $<0.05$. Initially, the average efficiency for the contraceptive implant was ranked as 2.44 which decreased to 1.89 after the workshop with a p-value of 0.036 . The perceived efficiency of over the counter pills (OCP) in the pre-workshop test was 2.44 which increased to 3.02 after the workshop with a

Table 2: Pre and Post Workshop perceptions on LARC use.

\begin{tabular}{|c|c|c|c|c|c|c|c|c|c|c|c|c|c|c|}
\hline & \multicolumn{2}{|c|}{$\begin{array}{l}\text { Tubal Ligation } \\
\text { is More } \\
\text { Effective Than } \\
\text { IUD (False) }\end{array}$} & \multicolumn{2}{|c|}{$\begin{array}{l}\text { Paraguard Can } \\
\text { Be Used for } \\
\text { Emergency } \\
\text { Contraception } \\
\text { (True) }\end{array}$} & \multicolumn{2}{|c|}{$\begin{array}{c}\text { Mirena } \\
\text { Can Be } \\
\text { Used for } \\
\text { Emergency } \\
\text { Contraception } \\
\text { (False) }\end{array}$} & \multicolumn{2}{|c|}{$\begin{array}{c}\text { IUD Can Be } \\
\text { Used Up to } \\
5 \text { Days Post } \\
\text { Intercourse } \\
\text { for Emergency } \\
\text { Contraception } \\
\text { (True) }\end{array}$} & \multicolumn{2}{|c|}{$\begin{array}{l}\text { Ocps Are } \\
\text { Cheaper then } \\
\text { IUD Over } 3 \\
\text { Years (False) }\end{array}$} & \multicolumn{2}{|c|}{$\begin{array}{c}\text { IUD Associated } \\
\text { with Increased } \\
\text { Risk of Ectopic? } \\
\text { (False) }\end{array}$} & \multicolumn{2}{|c|}{$\begin{array}{l}\text { IUD Associated } \\
\text { with Increased } \\
\text { Risk of Wt } \\
\text { Gain? (False) }\end{array}$} \\
\hline & True & False & True & False & True & False & True & False & True & False & True & False & True & False \\
\hline $\begin{array}{c}\text { Pre- } \\
\text { Workshop }\end{array}$ & 0.5 & 0.5 & 0.3333 & 0.6667 & 0.35 & 0.65 & 0.6098 & 0.3902 & 0.4872 & 0.5128 & 0.55 & 0.45 & 0.475 & 0.525 \\
\hline $\begin{array}{c}\text { Post- } \\
\text { Workshop }\end{array}$ & 0.2564 & 0.7436 & 0.8205 & 0.1795 & 0.359 & 0.641 & 0.8205 & 0.1795 & 0.2308 & 0.7692 & 0.3846 & 0.6154 & 0.2821 & 0.7179 \\
\hline$P$ value & 0.03 & & 0.0001 & & 0.868 & & 0.021 & & 0.022 & & 0.174 & & 0.095 & \\
\hline
\end{tabular}

Table 2 shows the change in responses to various perceptions about LARC use. Initially, 50\% of participants did not think that Tubal ligation is more effective than IUD. After the workshop, $74.4 \%$ of participants did not think that tubal ligation is more effective than IUD and $25.6 \%$ did think it was more effective ( $p$-value 0.03). When looking at the use of Paraguard in emergency contraception, pre-workshop $33.3 \%$ of applicants thought it could be used in emergency while $66.7 \%$ thought it could not be. Post workshop, $82 \%$ thought it could be used as emergency contraception while $18 \%$ thought it could not (p-value 0.0001 ). Additionally, when asked about the use of Mirena as emergency contraception, $65 \%$ of participants did not think that it could be used while $35 \%$ did think it could be used. After the workshop, p-value of 0.005. Additionally, changes in perceptions about the efficiency of using a Condom, IUD, and withdrawal method were also seen but with $\mathrm{p}$ values $>0.05$. Initially, the average efficiency for condoms was ranked at 3.13 and after the workshop, the average increased to 3.56 ( $p$-value $=0.069$ ). The average efficiency of IUD use was 2.43 and decreased to 1.97 with a p-value of 0.111 and the average efficiency of the withdrawal method was 4.51 before the workshop and 4.57 after the workshop with a p-value of 0.85 (Table 1).
$64.1 \%$ thought it could be used while $35.9 \%$ did not think it could be used for emergency contraception ( $p=$ value 0.87). When asked about how long after intercourse an IUD can be used as emergency contraception, 39\% thought it could not be used for up to 5 days afterwards while $70 \%$ did think it could be used. After the workshop, $18 \%$ thought it could not be used for up to 5 days after intercourse while $82 \%$ did think it could be used ( $p$-value $=0.02$ ). When asked to assess the statement "OCPs are cheaper than IUD over the course of 3 years", before the workshop $52.3 \%$ of participants thought this was false while $48.7 \%$ thought this was true. After the workshop, $77 \%$ of participants thought this was false and $23 \%$ thought this was true $(p=0.02)$. When asked about risks associated with IUD use, before the workshop 
$55 \%$ of participants thought that IUD use was associated with increased risk of ectopic pregnancy while $45 \%$ did not. After the workshop, $61.5 \%$ of participants did not think that IUD use was associated with an increased risk of ectopic pregnancy while $38.5 \%$ thought there was an increased risk ( $p$-value=0.174). Lastly, before the workshop $52.5 \%$ of participants disagreed with the statement that "IUDs are associated with increased risk of weight gain" while $47.5 \%$ agreed. After the workshop, $71.8 \%$ thought it was a false statement while $28.2 \%$ thought it was a true statement $(\mathrm{p}$-value $=0.10)$

When looking at demographic data such as gender, table 3.1 shows that the average perception of effectiveness of OCPs among females changed from 2.321 to 3.080 with a p-value of
0.0005. Females also changed their perception of IUDs from 2.552 to 1.772 with a p-value of 0.013 . Other perception changes from pre-workshop to post-workshop among females showed a $p$-value $>0.05$. The perceived efficiency of condoms decreased from 3.036 to 3.520 , Implant efficiency perceptions increased from 2.464 to 2.000 , and withdrawal's perceived efficiency decreased from 4.571 to 4.692 . Similarly, with males table 4.1 shows that all the changes in perceptions of the efficiency of various contraceptive methods had a $p$-value of $>0.05$. The perceived efficiency of condoms decreased from 3.264 to 3.636 , the perceived efficiency of implants increased from 2.364 to 1.626 , the perceived efficiency of OCPs decreased from 2.818 to 2.909 , and the perceived efficiency of withdrawal increased from 4.364 to 4.273 .

Table 3.1: Percieved efficiency of contraceptive methods in females ( $1=$ most efficient, $5=$ least efficient).

\begin{tabular}{|c|c|c|c|c|c|}
\hline & \multicolumn{3}{|c|}{ Efficiency of Contraceptive Methods (Scale of 1-5) } \\
\hline Females & Condom & Implant & OCP & IUD & 2.552 \\
\hline Pre workshop & 3.036 & 2.464 & 2.321 & 4.571 \\
\hline post workshop & 3.52 & 2 & 3.08 & 1.72 & 0.013 \\
\hline p value & 0.109 & 0.135 & 0.0005 & 0.708 \\
\hline
\end{tabular}

Table 3.2: Perceptions about LARC use among females.

\begin{tabular}{|c|c|c|c|c|c|c|c|c|c|c|c|c|c|c|}
\hline & \multicolumn{14}{|c|}{ Perceptions about LARC Use (Females) } \\
\hline & \multicolumn{2}{|c|}{$\begin{array}{l}\text { Tubal Ligation } \\
\text { is More } \\
\text { Effective Then } \\
\text { IUD (False) }\end{array}$} & \multicolumn{2}{|c|}{$\begin{array}{l}\text { Paraguard can } \\
\text { be used for } \\
\text { Emergency } \\
\text { Contraception } \\
\text { (True) }\end{array}$} & \multicolumn{2}{|c|}{$\begin{array}{l}\text { Mirena can } \\
\text { be Used for } \\
\text { Contraception } \\
\text { (False) }\end{array}$} & \multicolumn{2}{|c|}{$\begin{array}{l}\text { IUD can be } \\
\text { used Up to } \\
5 \text { Days Post } \\
\text { Intercourse } \\
\text { for Emergency } \\
\text { Contraception }\end{array}$} & \multicolumn{2}{|c|}{$\begin{array}{c}\text { Ocps are } \\
\text { Cheaper Then } \\
\text { IUD Over } 3 \\
\text { Years (False) }\end{array}$} & \multicolumn{2}{|c|}{$\begin{array}{c}\text { IUD Associated } \\
\text { with Increased } \\
\text { Risk of Ectopic? } \\
\text { (False) }\end{array}$} & \multicolumn{2}{|c|}{$\begin{array}{c}\text { IUD Associated } \\
\text { with Increased } \\
\text { Risk of Wt Gain? } \\
\text { (False) }\end{array}$} \\
\hline & True & False & True & False & True & False & True & False & True & False & True & False & True & False \\
\hline \multirow{2}{*}{$\begin{array}{c}\text { Pre- } \\
\text { Workshop }\end{array}$} & 46.67 & 53.33 & 30.00 & 70.00 & 27.59 & 72.41 & 51.72 & 48.28 & 51.85 & 48.15 & 50.00 & 50.00 & 53.57 & 46.43 \\
\hline & $\%$ & $\%$ & $\%$ & $\%$ & $\%$ & $\%$ & $\%$ & $\%$ & $\%$ & $\%$ & $\%$ & $\%$ & $\%$ & $\%$ \\
\hline \multirow{2}{*}{$\begin{array}{c}\text { Post- } \\
\text { Workshop }\end{array}$} & 22.22 & 77.78 & 81.48 & 18.52 & 40.74 & 59.26 & 85.19 & 14.81 & 29.63 & 70.37 & 37.04 & 62.96 & 25.93 & 74.07 \\
\hline & $\%$ & $\%$ & $\%$ & $\%$ & $\%$ & $\%$ & $\%$ & $\%$ & $\%$ & $\%$ & $\%$ & $\%$ & $\%$ & $\%$ \\
\hline$P$ value & 0.055 & & 0.0001 & & 0.308 & & 0.007 & & 0.1 & & 0.3417 & & 0.037 & \\
\hline
\end{tabular}

When females were asked about various perceptions regarding LARC use, three statements saw a significant change from pre-workshop and post-workshop answers with p-values $<0.05$ (Table 3.2). Before the workshop, 30\% of women agreed that Paraguard can be used for emergency contraception and after the workshop, 81.5\% of women agreed (p-value=0.0001). Before the workshop, $51.8 \%$ of women agreed that IUDs can be used up to 5 days post intercourse for emergency contraception and after the workshop, 85.2\% of women agreed (p-value=0.007). Furthermore, before the workshop, $46.4 \%$ of women disagreed with the false statement "IUDs are associated with weight gain" and after the workshop 74.1\% disagreed (p-value=0.037). All other statements saw a change in perceptions but with p-values $>0.05$. In male responses, Table 4.1 , there was only a significant change in perception of emergency use of Paraguard. Before the workshop, $41.7 \%$ of males agreed with the statement that Paraguard can be used for emergency contraception. After the workshop $90.9 \%$ of men agreed with the statement ( $p$ value $=0.012$ ). All other statements saw changes but with p-values $>0.05$ (Table 4.2).

Table 4.1: Percieved efficiency of contraceptive methods in males ( $1=$ most efficient, $5=$ least efficient).

\begin{tabular}{|c|c|c|c|c|c|}
\hline Males & \multicolumn{5}{|c|}{ Efficiency of Contraceptive Methods (Scale of 1-5) } \\
\hline & Condom & Implant & OCP & IUD & Withdraw \\
\hline $\begin{array}{c}\text { Pre } \\
\text { workshop }\end{array}$ & 3.364 & 2.364 & 2.818 & 2.091 & 4.364 \\
\hline $\begin{array}{c}\text { Post } \\
\text { workshop }\end{array}$ & 3.636 & 1.636 & 2.909 & 2.545 & 4.273 \\
\hline \begin{tabular}{c} 
p value \\
\hline
\end{tabular} & 0.439 & 0.143 & 0.843 & 0.407 & 0.891 \\
\hline
\end{tabular}


Table 4.2: Perceptions about LARC use among males.

\begin{tabular}{|c|c|c|c|c|c|c|c|c|c|c|c|c|c|c|}
\hline & \multicolumn{2}{|c|}{$\begin{array}{c}\text { Tubal } \\
\text { Ligation } \\
\text { is More } \\
\text { Effective then } \\
\text { IUD (False) }\end{array}$} & \multicolumn{2}{|c|}{$\begin{array}{l}\text { Paraguard can } \\
\text { be used for } \\
\text { Emergency } \\
\text { Contraception } \\
\text { (True) }\end{array}$} & \multicolumn{2}{|c|}{$\begin{array}{l}\text { Mirena can } \\
\text { be used for } \\
\text { Contraception } \\
\text { (False) }\end{array}$} & \multicolumn{2}{|c|}{$\begin{array}{l}\text { IUD Can be } \\
\text { used Up to } \\
5 \text { Days Post } \\
\text { Intercourse } \\
\text { for Emergency } \\
\text { Contraception } \\
\text { (True) }\end{array}$} & \multicolumn{2}{|c|}{$\begin{array}{c}\text { Ocps are } \\
\text { Cheaper Then } \\
\text { IUD Over } 3 \\
\text { Years (False) }\end{array}$} & \multicolumn{2}{|c|}{$\begin{array}{c}\text { IUD Associated } \\
\text { with Increased } \\
\text { Risk of Ectopic? } \\
\text { (False) }\end{array}$} & \multicolumn{2}{|c|}{$\begin{array}{l}\text { IUD Associated } \\
\text { with Increased } \\
\text { Risk of Wt } \\
\text { Gain? (False) }\end{array}$} \\
\hline & True & False & True & False & True & False & True & False & True & False & True & False & True & False \\
\hline $\begin{array}{c}\text { Pre- } \\
\text { Workshop }\end{array}$ & $\begin{array}{c}58.33 \\
\%\end{array}$ & $\begin{array}{c}41.67 \\
\%\end{array}$ & $\begin{array}{c}41.67 \\
\%\end{array}$ & $\begin{array}{c}58.33 \\
\%\end{array}$ & $\begin{array}{c}54.55 \\
\%\end{array}$ & $\begin{array}{c}45.45 \\
\%\end{array}$ & $\begin{array}{c}83.33 \\
\%\end{array}$ & $\begin{array}{c}16.67 \\
\%\end{array}$ & $\begin{array}{c}41.67 \\
\%\end{array}$ & $\begin{array}{c}58.33 \\
\%\end{array}$ & $\begin{array}{c}66.67 \\
\%\end{array}$ & $\begin{array}{c}33.33 \\
\%\end{array}$ & $\begin{array}{c}33.33 \\
\%\end{array}$ & $\begin{array}{c}66.67 \\
\%\end{array}$ \\
\hline $\begin{array}{c}\text { Post- } \\
\text { Workshop }\end{array}$ & $\begin{array}{c}36.36 \\
\%\end{array}$ & $\begin{array}{c}63.64 \\
\%\end{array}$ & $\begin{array}{c}90.91 \\
\%\end{array}$ & $\begin{array}{c}9.09 \\
\%\end{array}$ & $\begin{array}{c}27.27 \\
\%\end{array}$ & $\begin{array}{c}72.73 \\
\%\end{array}$ & $\begin{array}{c}81.82 \\
\%\end{array}$ & 18.18 & $\begin{array}{c}9.09 \\
\%\end{array}$ & 90.91 & $\begin{array}{c}45.45 \\
\%\end{array}$ & 54.55 & $\begin{array}{c}36.36 \\
\%\end{array}$ & 63.64 \\
\hline$P$ value & 0.314 & & 0.012 & & 0.211 & & 0.928 & & 0.081 & & 0.327 & & 0.886 & \\
\hline
\end{tabular}

Table 5.1: Percieved efficiency of contraceptive methods in Private university students ( 1 =most efficient, $5=$ =least efficient).

\begin{tabular}{|c|c|c|c|c|c|}
\hline $\begin{array}{c}\text { Private } \\
\text { University }\end{array}$ & \multicolumn{5}{|c|}{ Efficiency of Contraceptive Methods (Scale of 1-5) } \\
\hline & Condom & Implant & OCP & IUD & Withdraw \\
\hline $\begin{array}{c}\text { Pre- } \\
\text { workshop }\end{array}$ & 3.278 & 2.111 & 2.444 & 2.611 & 4.556 \\
\hline $\begin{array}{c}\text { post- } \\
\text { workshop }\end{array}$ & 3.611 & 1.778 & 2.944 & 1.889 & 4.778 \\
\hline \begin{tabular}{c} 
p value \\
\hline
\end{tabular} & 0.309 & 0.344 & 0.033 & 0.089 & 0.56 \\
\hline
\end{tabular}

When looking at private university students, we found there was a significant change in perception regarding the efficiency of OCPs before and after the workshop (Table 5.1). Before the workshop, the average effectiveness of OCPs was ranked at 2.44 while after the workshop, the average effectiveness of OCPs was ranked at 2.94 ( $p$-value=0.033). All other perceived efficiencies saw a change before and after the workshop but with p-values $>0.05$. The perceived efficiency of condoms changed from 3.28 to 3.61 , implants changed from 2.11 to 1.78 , IUDs changed from
2.61 to 1.89 , withdraw perceived efficiency changed from 4.56 to 4.78 (Table 5.1). When assessing public university students, we saw changes in perceived efficiency from pre-workshop to postworkshop, however all had p-values $>0.05$. The ranked efficiency for condoms changed from 3.00 to 3.5 , for implants it changed from 2.71 to 2.00 , for OCPs it changed from 2.48 to 3.11, for IUDs it changed from 2.27 to 2.08 , for withdraw it changed from 4.48 to 4.368 (Table 6.1).

Table 6.1: Percieved efficiency of contraceptive methods in Public University students ( $1=$ most efficient, $5=$ =least efficient).

\begin{tabular}{|c|c|c|c|c|c|}
\hline \multirow{2}{*}{$\begin{array}{c}\text { Public } \\
\text { University }\end{array}$} & \multicolumn{5}{|c|}{ Efficiency of Contraceptive Methods (Scale of 1-5) } \\
\cline { 2 - 6 } & Condom & Implant & OCP & IUD & Withdraw \\
\hline $\begin{array}{c}\text { Pre } \\
\text { workshop }\end{array}$ & 3 & 2.714 & 2.476 & 2.273 & 4.476 \\
\hline $\begin{array}{c}\text { Post } \\
\text { workshop }\end{array}$ & 3.5 & 2 & 3.111 & 2.056 & 4.368 \\
\hline p value & 0.145 & 0.059 & 0.056 & 0.581 & 0.811 \\
\hline
\end{tabular}

Table 5.2: Perceptions about LARC use among private university students.

\begin{tabular}{|c|c|c|c|c|c|c|c|c|c|c|c|c|c|c|}
\hline & \multicolumn{2}{|c|}{$\begin{array}{l}\text { Tubal } \\
\text { Ligation } \\
\text { is More } \\
\text { Effective } \\
\text { Then IUD } \\
\text { (False) }\end{array}$} & \multicolumn{2}{|c|}{$\begin{array}{c}\text { Paraguard can } \\
\text { be Used for } \\
\text { Emergency } \\
\text { Contraception } \\
\text { (True) }\end{array}$} & \multicolumn{2}{|c|}{$\begin{array}{c}\text { Mirena can } \\
\text { be Used for } \\
\text { Contraception } \\
\text { (False) }\end{array}$} & \multicolumn{2}{|c|}{$\begin{array}{c}\text { IUD can be } \\
\text { Used Up To } \\
5 \text { Days Post } \\
\text { Intercourse } \\
\text { for Emergency } \\
\text { Contraception } \\
\text { (True) }\end{array}$} & \multicolumn{2}{|c|}{$\begin{array}{c}\text { Ocps are } \\
\text { Cheaper Then } \\
\text { IUD Over } 3 \\
\text { Years (False) }\end{array}$} & \multicolumn{2}{|c|}{$\begin{array}{c}\text { IUD Associated } \\
\text { with Increased } \\
\text { Risk of } \\
\text { Ectopic? } \\
\text { (False) }\end{array}$} & \multicolumn{2}{|c|}{$\begin{array}{c}\text { IUD Associated } \\
\text { with Increased } \\
\text { Risk of Wt Gain? } \\
\text { (False) }\end{array}$} \\
\hline & True & False & True & False & True & False & True & False & True & False & True & False & True & False \\
\hline $\begin{array}{c}\text { Pre- } \\
\text { Workshop }\end{array}$ & $\begin{array}{c}57.89 \\
\%\end{array}$ & $\begin{array}{c}42.11 \\
\%\end{array}$ & $\begin{array}{c}26.32 \\
\%\end{array}$ & $\begin{array}{c}73.68 \\
\%\end{array}$ & $\begin{array}{c}33.33 \\
\%\end{array}$ & $\begin{array}{c}66.67 \\
\%\end{array}$ & $\begin{array}{c}68.42 \\
\%\end{array}$ & $\begin{array}{c}31.58 \\
\%\end{array}$ & $\begin{array}{c}27.78 \\
\%\end{array}$ & $\begin{array}{c}72.22 \\
\%\end{array}$ & $\begin{array}{c}55.56 \\
\%\end{array}$ & $\begin{array}{c}44.44 \\
\%\end{array}$ & $\begin{array}{c}33.33 \\
\%\end{array}$ & $\begin{array}{c}66.67 \\
\%\end{array}$ \\
\hline $\begin{array}{c}\text { Post- } \\
\text { Workshop }\end{array}$ & $\begin{array}{c}35.29 \\
\%\end{array}$ & $\begin{array}{c}64.71 \\
\%\end{array}$ & $\begin{array}{c}88.24 \\
\%\end{array}$ & $\begin{array}{c}11.76 \\
\%\end{array}$ & $\begin{array}{c}35.29 \\
\%\end{array}$ & $\begin{array}{c}64.71 \\
\%\end{array}$ & $\begin{array}{c}94.12 \\
\%\end{array}$ & $\begin{array}{c}5.88 \\
\%\end{array}$ & $\begin{array}{c}11.76 \\
\%\end{array}$ & $\begin{array}{c}88.24 \\
\%\end{array}$ & $\begin{array}{c}35.29 \\
\%\end{array}$ & $\begin{array}{c}64.71 \\
\%\end{array}$ & $\begin{array}{c}29.41 \\
\%\end{array}$ & $\begin{array}{c}70.59 \\
\%\end{array}$ \\
\hline$P$ value & 0.142 & & 0.0002 & & 1 & & 0.138 & & 0.218 & & 0.19 & & 0.727 & \\
\hline
\end{tabular}

Among private university students, the most significant change was seen in response to using IUDs as emergency contraception. Before the workshop, $26.3 \%$ of students agreed that Paraguard can be used as emergency contraception and after the workshop, 88.2\% agreed (p-value=0.0002). All other statements saw a change in the percentage that answered right with p-values $>0.05$ (Table 5.2). In public university students, the same statement saw a significant change after the workshop. 
Before the workshop, 39.1\% agreed that Paraguard can be used for emergency contraception. After the workshop, 85\% agreed ( $p$-value $=0.002$ ). Another significant change was seen regarding the false statement that "OCPs are cheaper than IUD over 3 years". Before the work shop, $33.3 \%$ of students said this was false and after the workshop the percentage that answered false rose to $65 \%$ ( $p$-value=0.044). All other statements also saw a change in before and after responses to statements with p-values $>0.05$ (Table 6.2).

Table 6.2

\begin{tabular}{|c|c|c|c|c|c|c|c|c|c|c|c|c|c|c|}
\hline & \multicolumn{2}{|c|}{$\begin{array}{l}\text { Tubal } \\
\text { Ligation } \\
\text { is more } \\
\text { Effective } \\
\text { Then IUD } \\
\text { (False) }\end{array}$} & \multicolumn{2}{|c|}{$\begin{array}{l}\text { Paraguard can } \\
\text { be Used for } \\
\text { Emergency } \\
\text { Contraception } \\
\text { (True) }\end{array}$} & \multicolumn{2}{|c|}{$\begin{array}{l}\text { Mirena Can } \\
\text { be Used for } \\
\text { Contraception } \\
\text { (False) }\end{array}$} & \multicolumn{2}{|c|}{$\begin{array}{l}\text { IUD Can be } \\
\text { Used up to } \\
5 \text { Days Post } \\
\text { Intercourse } \\
\text { for Emergency } \\
\text { Contraception } \\
\text { (True) }\end{array}$} & \multicolumn{2}{|c|}{$\begin{array}{c}\text { Ocps are } \\
\text { Cheaper then } \\
\text { IUD Over } 3 \text { Years } \\
\text { (False) }\end{array}$} & \multicolumn{2}{|c|}{$\begin{array}{c}\text { IUD Associated } \\
\text { with Increased } \\
\text { Risk of Ectopic? } \\
\text { (False) }\end{array}$} & \multicolumn{2}{|c|}{$\begin{array}{c}\text { IUD Associated } \\
\text { with Increased } \\
\text { Risk of Wt Gain? } \\
\text { (False) }\end{array}$} \\
\hline & True & False & True & False & True & False & True & False & True & False & True & False & True & False \\
\hline \multirow{2}{*}{$\begin{array}{c}\text { Pre- } \\
\text { Workshop }\end{array}$} & 43.48 & 56.52 & 39.13 & 60.87 & 36.36 & 63.64 & 54.55 & 45.45 & 66.67 & 33.33 & 54.55 & 45.45 & 59.09 & 40.91 \\
\hline & $\%$ & $\%$ & $\%$ & $\%$ & $\%$ & $\%$ & $\%$ & $\%$ & $\%$ & $\%$ & $\%$ & $\%$ & $\%$ & $\%$ \\
\hline \multirow{2}{*}{$\begin{array}{c}\text { Post- } \\
\text { Workshop }\end{array}$} & 20.00 & 80.00 & 85.00 & 15.00 & 40.00 & 60.00 & 80.00 & 20.00 & 35.00 & 65.00 & 45.00 & 55.00 & 30.00 & 70.00 \\
\hline & $\%$ & $\%$ & $\%$ & $\%$ & $\%$ & $\%$ & $\%$ & $\%$ & $\%$ & $\%$ & $\%$ & $\%$ & $\%$ & $\%$ \\
\hline$P$ value & 0.106 & & 0.002 & & 0.814 & & 0.081 & & 0.044 & & 0.548 & & 0.061 & \\
\hline
\end{tabular}

\section{Discussion}

This study confirmed that misconceptions about LARC use are still widespread. Though educating young adults about LARCs, there can be better awareness and knowledge to support their use in general populations. For example, the perceived efficiency of implants saw a significant increase after the workshop session. Furthermore, many of the true or false questions asked about LARC use played off misconceptions in the general public. We saw that after the workshop, there was a significant shift in the percentage of people identifying the statement correctly as either true or false. Based off the results, some common misconceptions that were significantly clarified after educational intervention were: Tubal ligation is more effective than IUDs, Paraguard can be used for emergency contraception, IUDs can be used as emergency contraception for up to 5 days post intercourse, and that OCPs are cheaper than IUDs over the course of 3 years.

The results of our study highlight the importance of education in eliminating perception barriers that are common in adolescent populations. The American college of Obstetricians and Gynecologists recommend physicians to encourage LARC methods for use by adolescents. In order to do this, they recommend counseling and education to occur at all health provider visits with sexually active adolescents $[10,12]$. While studies have shown that education is needed to help adolescents make decisions, the exact method has not been defined. In one study conducted, they concluded that giving empirical or anecdotal information about LARCs to adolescents does not work as efficiently as given straightforward information that address the advantages and potential disadvantages of LARC $[13,14]$. Our study conducted an intervention and workshop that gave straightforward information and from the results of the post-workshop data, we can see the effect of this method.
However, education is not the only barrier to LARC use. In order to reduce rates of pregnancy in adolescents, it is critical to identify and address all the various barriers. While education is the most effective method to increase compliance and overcome perceptions, we must address other concerns such as social stigma, financial, long-term effects, and weight gain $[15,16]$.

We also studied the differences between demographics groups such as gender and students from private versus public universities. When comparing males and females, the perception of efficiency of various contraceptives saw no significant change in the rankings from before to after the workshop in males. However, in females, both the efficiency of OCP use and the efficiency of IUD use saw a significant change from the average ranking before the workshop to the average ranking after the workshop. In regards to perceptions about LARC use, women saw a significant change in their perceptions regarding the emergency use of Paraguard, the length of time for which IUDs can be used as emergency contraceptive, and regarding the associated side effects of IUDs. However, the male group only saw a change in their perceptions regarding the use of Paraguard for emergency contraceptive. The reasons behind this discrepancy could be because the educational intervention was more effective in women than men or perhaps because of the small sample size of men in our study. This demographic comparison should be done again with a larger number of males in the study.

Among private university students, the most significant perception change regarding contraceptive efficiency that was seen was about the efficiency of OCPs. On the other hand, in students who attended a public university, there were no significant changes in the perception of efficiency before and after the workshop for any of the contraceptives. Furthermore, in students who attended a private university had a significant change in the in regards to their perceptions of using Paraguard 
as an emergency contraceptive. Among public university students, the same perception that saw a change in response from before to after the workshop was about using Paraguard as emergency contraceptives. Public university students as also showed a significant change in their perception about the costs of IUDs compared to OCPs. The potential reasons for the discrepancy between the two groups includes factors such as what education about LARCs and contraceptives that had already been given to students in public v. private universities or the difference in sample size between the two groups. To further studies on this topic such be done with a bigger sample size for each population as well as looking into education programs that students at different universities are exposed to.

There was one instance in which the percentage of participates who answered the statement correctly actually decreased. When asked to identify the validity of the statement "Mirena can be used for emergency contraception", 65\% of participants accurately identified it as a false statement before the workshop, while after the workshop this percentage went down to $64 \%$. While this is not a significant change, we attribute this change to a slight change in sample size that was already small to begin with. Another area of discrepancy was in the demographic comparison in which the average ranked efficiency of withdrawal as a contraceptive actually saw a slight increase. While this slight increase was not found to be statistically significant, we hypothesize that this may change may be due to a smaller sample size as well.

The strengths of this study include a well-planned out workshop and strong survey questions. These questions very accurately reflect the misconceptions of LARCs that exist in the general population. However, if we were to repeat this study, we would try this intervention on a larger sample size to get an even more accurate representation. In future studies there would be a benefit to assess a more diverse population and studying the responses according to race and class. There have always been many barriers to access of contraceptives in general, but especially LARCs. By studying different populations for educational interventions, we may be able to illuminate one of the many barriers. It would also be of great use to identify barriers other than financial and educational such as, social or access to physicians who perform these procedures. By identifying barriers, we can further eliminate them.

Despite the overall increase in use of LARCs in the last couple of years, there continue to be a variety of barriers to LARCs. This study demonstrated how misconceptions regarding LARCs continue to prevent their use in young, well-educated populations and showed a modality for improving knowledge deficiencies that can be used.

\section{References}

1. American College of Obstetricians and Gynecologists (2015) Increasing Access to Contraceptive Implants and Intrauterine Devices to Reduce Unintended Pregnancy. Committee Opinion No. 642. Obstetrics and Gynecology 126: 44-48.

2. Luchowski AT, Anderson BL, Power ML, Raglan GB, Espey E, et al. (2014) Obstetrician-Gynecologists and contraception: Long-acting reversible contraception practices and education. Contraception 89(6): 578-583.

3. Stanford JB, Mikolajczyk RT (2002) Mechanisms of action of intrauterine devices: Update and estimation of postfertilization effects. Am J Obstet Gynecol 187(6): 1699-1708.

4. Committee on Adolescent Health Care Long-Acting Reversible Contraception Working Group, \& ACOG (2012) Committee Opinion no. 539: Adolescents and Long-Acting Reversible Contraception: Implants and Intrauterine Devices. Obstetrics and Gynecology 120(4): 983-988.

5. Leeman L (2007) Medical Barriers to Effective Contraception. Obstet Gynecol Clin North Am 34(1): 19-29.

6. Jacobstein R, Polis CB (2014) Progestin-only contraception: Injectables and implants. Best Pract Res Clin Obstet Gynaecol 28(6): 795-806.

7. Croxatto HB (2002) Mechanisms that explain the contraceptive action of progestin implants for women. Contraception 65(1): 21-27.

8. Díaz, S, Pavez M, Moo-Young AJ, Bardin CW, Croxatto HB (1991) Clinical trial with 3-keto-desogestrel subdermal implants. Contraception 44(4): 393-408.

9. Mäkäräinen L, Van Beek A, Tuomivaara L, Asplund B, Bennink HC (1998) Ovarian function during the use of a single contraceptive implant: Implanon compared with Norplant. Fertility and Sterility 69(4): 714-721.

10. Murphy MK, Stoffel C, Nolan M, Haider S (2016) Interdependent Barriers to Providing Adolescents with Long-Acting Reversible Contraception: Qualitative Insights from Providers. J Pediatr Adolesc Gynecol 29(5): 436-442.

11. The American College of Obstetricians and Gynecologists Women's Health Care Physicians. (2012) Adolescents and Long-Acting Reversible Contraception : Implants and Intrauterine Devices. Committe Opinion 120(4): 983-988.

12. Trussell J, Lalla AM, Doan QV, Reyes E, Pinto L, et al. (2009) Cost effectiveness of contraceptives in the United States. Contraception 79(1): 5-14.

13. Teal SB, Romer SE (2013) Awareness of long-acting reversible contraception among teens and young adults. J Adolesc Health 52(4 Suppl): S35-S39.

14. Apter D (2012) Adolescent contraception. In: Sultan C (Ed.), Pediatric and Adolescent Gynecology. Evidence-Based Clinical Practice, 22: 287301.

15. American Congress of Obstetricians and Gynecologists (2011) LongActing Reversible Contraception: Implants and Intrauterine Devices. ACOG Practice Bulletins.

16. Curtis KM, Tepper NK, Marchbank PA (2011) US medical eligibility criteria for contraceptive use, 2010. Journal of Women's Health 20(6): 825-828. 
(C) This work is licensed under Creative
Your next submission with Juniper Publishers will reach you the below assets

- Quality Editorial service

- Swift Peer Review

- Reprints availability

- E-prints Service

- Manuscript Podcast for convenient understanding

- Global attainment for your research

- Manuscript accessibility in different formats ( Pdf, E-pub, Full Text, Audio)

- Unceasing customer service

Track the below URL for one-step submission https://juniperpublishers.com/online-submission.php 